\title{
Harry Thirlwall Norris 24 June 1926-10 January 2019
}

\author{
By Kristian Norris
}

Harry Thirlwall Norris's connections with Libya spanned 60 years and he was a member of the Society for Libyan Studies for many years until his death.

Harry Norris's story starts with his birth in Harrow, Middlesex. For his secondary education he was sent to Haberdashers in London. Part of his secondary education was also located at Paston Grammar School in North Walsham, Norfolk on account of the Second World War. With little entertainment and a curfew Harry was a young recruit to the Home Guard, serving both in Harrow and Mundesley-on-Sea. There were two events in 1944. His mother died in August; and weeks later Harry received his call up papers from the Army and reported to Britannia Barracks at Norwich for basic training. He received further training in Rhosneigr in north Wales and Stanmore in Middlesex. Next he was sent to Wentworth Woodhouse near Rotherham for Intelligence Corps training with a view to the war against Japan. However, that war ended in August 1945. His unit was billeted at Tempsford in Bedfordshire when the unit was ordered to Bengal in India. He had never been abroad before. His unit was 'air-trooped' in a converted Lancaster bomber to Karachi. He spent two years in India based mainly at Dacca, now capital of Bangladesh. During leave he travelled into the Himalayas, using the railway to Darjeeling. This allowed him to develop his oriental interests. The next two years were spent in the Intelligence Corps in the Palestine Campaign in 1946-48. He was initially moved to Egypt but spent the rest of the time in Jerusalem. It was here he had exposure to the Arab and Muslim world. He was demobilised in 1948.

His further education had been delayed for 4 years by the Army but in 1948 he started his degree course in Archaeology and Anthropology at Peterhouse in Cambridge University. He completed the courses in 2 years rather than the customary 3 , gaining a First in one of the two parts of the Tripos. During his studies he travelled to, and took part in, a dig at one of the classical sites in Libya.

Then he set off for a career in the Colonial Service. He received a year's training in Peter's

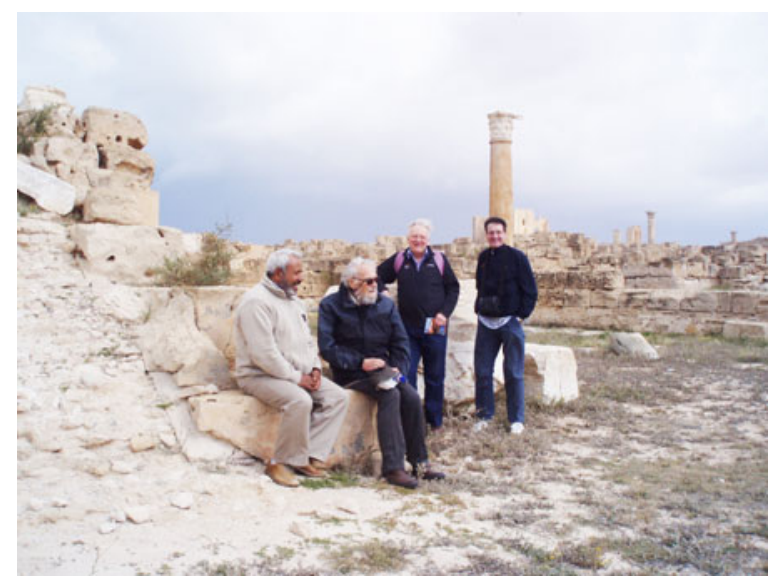

Figure 1. Harry Norris is second from the left, seated at Sabratha on 14 March 2010, the guide, Abdullah Abou Hamra, is on Harry's right (Photo: Vivien McCormick).

Hall in Oxford in 1950-1951. While at Oxford he met Karen his future wife from Denmark who was working just outside the city. They married in Copenhagen in 1954. Harry's Colonial Service career lasted until 1958. His first posting was in Aden Colony. Here he used his Arabic. He also participated on a survey of the Aden tanks. For health reasons his second posting was to Gibraltar. By 1958 the Colonial Service was being run down and he had to return to the UK to secure further employment.

He obtained a temporary post at the School of Oriental and African Studies, University of London (SOAS), teaching Arabic to Army officers. This was the start of 33 years at SOAS, from 1958 until retirement in 1991. His career progression was Junior Lecturer, Lecturer, Senior Lecturer, Reader and eventually Professor of Arabic and Islamic Studies. In later years he combined the professorial role with that of Dean of Undergraduate Studies. During this 33-year period and later in retirement he wrote 13 books, the first being Shinqiti Folk Literature and Song, published in 1968, which also formed his doctoral thesis. Other memorable books include Islam in the Balkans which appeared shortly before the Yugoslav wars broke out. Also Islam in the Baltic appeared before the mass migrations of 2015 to Sweden in particular. He travelled extensively 
during his university career. Between 1961-62 he spent a year on study leave in newly independent Mauretania and for a few years was a leading authority on that country. Later he had several study visits to Niger. He also visited the Western Sahara, Senegal, Mali and Morocco.

After he retired, he was very active until 2010 . He acted as a tour guide for Ace Cultural Tours, he also travelled to Nigeria to examine university theses. After 1986 he travelled to Serbia, Montenegro, Bosnia, Albania, Bulgaria and Romania which provided material for his book Islam in the Balkans. Later he travelled to Poland, Lithuania, Belarus, Latvia, Estonia, Finland and Sweden which fuelled another book, Islam in the Baltic.

He made many trips to Libya, and in 2002 went by Landrover to Fazzan as a guest of the Society for Libyan Studies and the Government of Libya. This was his last trip into the Sahara. But between 2004 and 2010 he made repeat visits to the Saharan oasis of Ghadames. These were facilitated by tours arranged through the travel firm Cox and Kings and he also visited other sites such as Leptis Magna. In
2004 he met Abd al-Jabbar b. Abd al-Qadir al-Saghir 'Abou Zeid' from Ghadames who supplied him with forty Arabic texts from his collection. Harry then proceeded to produce translations of these texts which were the focus of his last book Arabic Historical Literature from Ghadamis and Mali Documents from the $18^{\text {th }}$ to $20^{\text {th }}$ Century. This was produced with the editorial help of a former student Knut Vikoer and published by Brill in December 2019. Harry's last visit to Libya was in March 2010. Again travelling with Cox and Kings he went to Ghadames. Later in 2010 he developed health problems and no further trips were made.

Harry Norris, over the course of his academic life, wrote numerous articles, including for Libyan Studies, volume 34, 2003: The Libyan Fazzan: a crossroads of routes and a thoroughfare of Arab and Berber tribes historically connected with the Murabitun (Almoravids). A historical and tribal reassessment in the light of what is discoverable in the historical literature. Both oral and recorded, of the Tuareg peoples of the Central Sahara and the Libyan Fazzan, 